\title{
ONLINE ENGLISH LANGUAGE TEACHING/LEARNING DURING THE COVID-19 PANDEMIC: STUDENTS' AND TEACHERS' PERCEPTIONS AT VILNIAUS KOLEGIJA/ UNIVERSITY OF APPLIED SCIENCES
}

\author{
Viktorija Prapraitė, Virginija Andriusevičienė
}

University of Applied Sciences

\begin{abstract}
The article analyzes the challenges posed by rapid shifting from face-to-face to online teaching/learning due to the Covid-19 pandemic. Along with other educational institutions Vilniaus kolegija/University of Applied Sciences had to switch to online teaching/ learning. After a year of new experience, a cross-sectional study was conducted to establish students' and teachers 'perceptions of online learning and highlight areas for improvement. Two surveys were conducted: a student survey $(N=39)$ and a teacher survey $(N=13)$. The findings revealed that the vast majority of the respondents in both groups feel fully or partially satisfied with online teaching/learning and academic achievements. Of the two main tools engaged in online teaching/learning preference is given to Microsoft Teams, leaving the Moodle platform slightly behind. The authors conclude that despite overall positive feedback some improvements are necessary to raise the quality of online teaching/learning. Further research would help to monitor the development of the situation.
\end{abstract}

Key words: higher education, language learning, online learning, Covid-19 pandemic.

\section{Introduction}

The COVID -19 pandemic situation has impacted the entire education system and brought a new phase in education which is marked by shifting form traditional face-to-face learning in classroom to online learning. Online learning has suddenly become a necessity rather than an option. It has become a must, whether we like it or not, and whether we are ready or not. Rapid solutions had to be made in spring of 2020 when the global pandemic was declared, which came as a great shock to many educational institutions all over the world. HE institutions started exploring and adopting instructional modes to manage the changing demands of education as they deal with COVID-19. Online learning is one of such modes. In many countries online learning seemed to be the only solution to continue providing educational services in the pandemic situation. In China, for example, where the pandemic started, 'there was an overnight shift of normal classrooms into e-classrooms, that 
is, educators have shifted their entire pedagogical approach to tackle new market conditions and adapt to the changing situations' (Dhawan, 2020).

Numerous definitions of online learning have been offered so far. Joshua Stern, $\mathrm{PhD}$, an online education and digital content specialist, founder and principal of Joshua Stern Educational Consulting (USA), defines online learning as 'education that takes place over the Internet.' It is often referred to as "e-learning" among other terms. However, online learning is just one type of "distance learning" - the umbrella term for any learning that takes place across distance and not in a traditional classroom. Distance learning has a long history and there are several types available today, including: Correspondence Courses (conducted through regular mail with little interaction), Telecourses (where content is delivered via radio or television broadcast), CD-ROM Courses (where the student interacts with static computer content), Online Learning (Internet-based courses offered synchronously and/ or asynchronously), and Mobile Learning (by means of devices such as cellular phones, PDAs and digital audio players (iPods, MP3 players)).' Obviously, by far the most popular approach today is online learning.

Online learning, or e-learning, is also defined as 'the learning supported with electronic technology like online classes and portals to access the courses outside the classroom' (Elumalai et all, 2020, p.732), or as 'electronic learning that includes all learning situations that employ the new technologies' (Ananga, 2020, p.312). Dhawan (2020, p.7) defines it as 'learning experiences in synchronous or asynchronous environments using different devices (e.g., mobile phones, laptops, etc.) with access to the internet'. In these environments, students can be anywhere to learn and interact with instructors and other students. The synchronous learning environment allows students attend live lectures, there are real-time interactions between educators and learners, and learners receive instant feedback, whereas in asynchronous learning environments learning content is not available in the form of live lectures or classes; it is available at different learning systems and forums. Instant feedback and immediate response are not possible under such an environment (Dhawan).

Rapid transition from face-to-face to online learning could not have been easy. Numerous issues had to be tackled with. The administrative staff had their concerns: their concern was not about whether online teaching-learning methods can provide quality education, it was rather how academic institutions will be able to adopt online learning in such a massive manner' (Dhawan, 2020). Moreover, the pandemic situation has revealed emerging vulnerabilities in education systems around the world. It has become apparent that society needs flexible and resilient education systems as we face unpredictable futures (Ali, 2020). Students also had a number of concerns, the main one being that online learning will affect the quality of education and its outcomes.

Regardless of all possible advantages and disadvantages, online teaching is a reality today that has to be embraced by all stakeholders. Vilniaus kolegija/ UAS shifted to online teaching at the beginning of the Covid-19 pandemic, moving 
on to hybrid teaching from September 1, 2021. The courses of foreign languages, including ESP, have been toughed exclusively online, the main tools used by teachers being Moodle and Microsoft Teams. After 2 semesters of online teaching/ learning, a study was conducted regarding the suitability of the above-mentioned tools for online language teaching/learning.

The aim of the study is to investigate undergraduate students' satisfaction with online courses of the English language and teachers' attitudes and concerns regarding online teaching at Vilniaus kolegija/UAS.

The research problem is students' (dis)satisfaction with a rapid transition to online learning and its possible effect on academic achievements. A hypothesis was made that students may feel dissatisfied with a drastic shift in the teaching/learning environment, tools and methods, and that this transition may negatively affect their academic achievements.

\section{The objectives of the research:}

1. Review scientific literature to overview the global situation in higher education in the pandemic conditions and establish current tendencies and challenges related to online teaching/learning;

2. Conduct a student survey to find out the level of satisfaction with online learning;

3. Conduct a teacher survey to find out teachers' attitudes and concerns regarding online teaching.

Research methodology and methods: literature review and a quantitative survey of students $(\mathrm{N}=39)$ and teachers $(\mathrm{N}=13)$.

The articles reviewed were all retrieved from EBSCOhost databases in the period from March to May, 2021 using key words 'online learning' and 'Covid-19'.

The students participating in the survey were all undergraduate students $\left(1^{\text {st }}, 2^{\text {nd }}\right.$ and $3^{\text {rd }}$ year) from the Faculty of Health Care $(\mathrm{N}=29)$ and the Faculty of Business ( $\mathrm{N}=10)$ of Vilniaus kolegija/UAS who studied English as the first foreign language in the autumn semester of the year 2020. From 71 eligible participants, 39 completed the online questionnaire (55\% response rate). The respondents had to complete a questionnaire that included 15 open-ended and closed-ended questions about their experience of using online learning platforms Moodle and Microsoft Teams for learning English as a foreign language.

The teacher survey involved 13 English language teachers (87\% response rate) from all seven faculties of Vilniaus kolegija/UAS. They had to complete a questionnaire with 30 open-ended and closed-ended questions.

\section{Literature review}

In the past year many researchers have focused on the subject of online learning, and many more will in the following years as the quality of online learning is, and will remain, a core issue in education. Review of the recent scientific publications reveals that factors affecting the quality of e-learning, teachers'/ 
students' readiness to deliver/receive quality online teaching, students' attitudes and concerns, pedagogical considerations of e-learning, the use of specific tools and methods emerge as the most discussed aspects of the subject.

Factors affecting the quality of e-learning include administrative support, course content, course design, instructor characteristics, learner characteristics, social support, and technical support. A cross-sectional study conducted in India and the Kingdom of Saudi Arabia with an aim to find out the tertiary level students' $(\mathrm{N}=784)$ perception of e-learning showed a positive relationship between the quality of e-learning and the seven factors that hypothetically affect the quality of e-learning. The findings clearly stated that administrative support and course content, two very important factors, require improvement to enhance the quality of e-learning. Further, it was revealed that there should be some improvisation in the course content accompanied with the technology to support blended e-learning. The authors concluded that the implementation of the e-learning procedure is in the hands of administrators, so the educational institutions need to consider the extent of the administrative support to enhance the quality of e-learning (Elumalai et al, 2020).

Another important question that arises naturally in today's situation is regarding our readiness to teach/learn in new conditions. Right at the beginning of this exceptional situation the teaching staff clearly faced serious problems, like ambiguity and disagreement about what to teach, how to teach, the workload of teachers and students, the teaching environment, and the implications for education equity (Ali, 2020). Naturally, teachers resorted to online teaching tools, but that was not easy: some of the staff members in a tertiary institution started integrating ICT in their lessons, however, majority (92\%) of them still believe that confidence needs to be enhanced. This lack of confidence could be due to the administration of the different tools and learning platforms (Ali). The primary areas where faculty and administrators identified a need for assistance were related to student support, greater access to online digital materials, and guidance for working from home (Johnson, Veletsianos \& Seaman, 2020). Technology management, support from institution management, increased student awareness to use E-learning systems and demanding a high level of information technology from teachers were among the main issues to tackle in many educational institutions (Alqahtani \& Rajkhan, 2020). Teachers had to assume an additional responsibility during the pandemic. They had to adjust themselves to a changing environment, getting their technical skills polished during the process, and providing facilitation of technical expertise to the students who are new to this environment (Baber, 2020). Shifting to complete online teaching involves a process by which the teacher's role transitions towards the curation of online and offline student experiences. This includes facilitating and blending extensive and intensive online learning experiences, which is no doubt challenging (Bryson \& Andres, 2020).

A new situation requires from the participants of the teaching/learning 
process certain skills and qualities, including technical skills, time management skills, communication skills, independent learning skills and strong motivation to learn. A study conducted among higher education students in Turkey revealed that self-directed learning followed by motivation toward e-learning are the strongest predictors of students' academic achievement, while computer selfefficacy, internet self-efficacy, online self-efficacy and learner control were not found to be strong predictors of academic success. Self-directed learners are those who can learn independently and independently pursue their own learning goals. Thus, as learning is a more individual and independent activity within the online learning process, motivation is therefore essential for effective online learning, and lack of motivation can be a factor determining students' failure to achieve learning outcomes (Torun, 2000). Students' motivation is emphasized by many researchers. Patricia Ananga (2020) states that due to the limited social interaction that exist between student-student and student-instructor, it is very necessary for the students to motivate themselves and have frequent communication to ensure that assigned tasks could be accomplished. Alqahtani \& Rajkhan (2020) claim that students must understand their role during the social distancing measures, build their own attitude and commitment, and find ways to self-motivate in order to gain successful learning outcomes. Thus, students' readiness for exclusively online learning is largely determined by their ability to learn independently and their motivation to do so.

A study on teachers' readiness to teach online during COVID-19 pandemic in Turkey $(\mathrm{N}=1016)$ demonstrated that most of the respondents admitted having difficulties and those difficulties included internet connection issues, lack of educatorstudent interaction, not being able to make a reliable assessment of learning, lack of knowledge about how to evaluate the learners' knowledge and skills, not being able to provide skills, not being able to reach all the learning outcomes, difficulty in providing feedback to students, difficulty in teaching according to the individual interests and abilities of the students, lack of student motivation, school/university administrators' attitude and behaviors towards educators who teach online during the obligatory online education period (Korkmaz \& Toraman, 2020).

Another study conducted in the USA ( $\mathrm{N}=897)$ revealed that not all teachers had previous experience of online teaching and after the shift to exclusively online teaching were in the process of learning how to teach online. To adapt to a new situation a majority of faculty reported making changes to their assignments or exams as a result of transitioning to a new mode of delivery. Nearly half reported lowering the expected volume of work for students (including dropping assignments or exams) and/or shifting to a pass/fail model for this semester (Johnson, Veletsianos \& Seaman, 2020).

Student satisfaction is a key factor in assessing the effectiveness of online learning. Several surveys regarding student satisfaction with online learning in Israel revealed that students are partially satisfied with this mode of learning and 
they see both advantages and disadvantages. The survey conducted at Tel Aviv University revealed that, on the plus side, students state that online learning gives them more flexibility to manage their time according to personal needs, more flexible study pace (they can listen to recordings of the lectures whenever and wherever convenient for them); saves time and money as they do not have to arrive at the campus; allowed the semester to continue and prevented its cancellation, which might have disrupted their studies. On the minus side, students claim that this teaching method leads to a drop in the quality of teaching, resulting both from the fact that some faculty members lack experience with this teaching pattern and find it hard to adjust to it. Students also reported a decline in motivation to study and a difficulty to maintain concentration when viewing an online lecture. A study conducted at Ariel university $(\mathrm{N}=1400)$ showed that advantages of online learning as seen by students are: no formal clothing (they can wear whatever they want) (68\%); the possibility to record lectures (that adds to the effectiveness of the teaching method) (44\%); and no attendance obligation (32\%). The most significant shortcoming ascribed to the online teaching method is students' inability to see their friends on campus $(52.6 \%)$ and reduced motivation leading to a decline in their studies' (27\%) (Cohen \& Davidovitch, 2020).

A study on students' attitudes and concerns conducted in Croatia ( $\mathrm{N}=2520)$ revealed that general satisfaction with exclusive e-learning was rated with average grade of 3.7 out of 5. Compared with previous (traditional) education, exclusive e-learning was rated with average grade of 3.2 out of 5. Compared to classroom learning, equal or higher motivation to attend exclusive e-learning was reported by $64.4 \%$ of participants. Less than half of the students indicated they felt deprived or concerned due to the lack of practical lessons. Most participants $(55.7 \%)$ indicated that in the future, they would prefer to combine classic classroom and e-learning (Puljak et al, 2020). Similar results were demonstrated by another study conducted in Turkey, where students showed overall satisfaction with online learning, especially when Microsoft Teams was used for live lessons (Durak \& Çankaya 2020).

In general, a positive trend has been observed in the development of students' reaction to the unexpected dramatic changes: at first it was rather negative as most students were expressing anxiety, uncertainty and nervousness toward online learning and fear that online learning will be different than standard in-class learning (Murphy, Eduljee \& Croteau, 2020; Unger \& Meiran, 2020). After the initial shock, however, both teachers and students demonstrated a range of attitudes about learning online: when asked to describe their feelings, they used from rather negative adjectives, such as challenging, overwhelming, stressful, difficult, tough, exhausting, to positive adjectives, such as revolutionary, dynamic, fun, efficient, temporary, interesting (Marshall \& Kostka, 2020). Some authors claim that transition from the traditional to the online education has been successful (Basilaia \& Kvavadze, 2020) 
Still few studies have been conducted regarding the efficiency of online learning in the field of foreign language studies or ESP. A study conducted in Indonesia among university students $(\mathrm{N}=214)$ who studied English for Electrical Engineering revealed that online learning in both synchronous and asynchronous method is as effective as face-to-face learning (Kusumawati, 2020).

\section{Analysis of Students' and Teachers' Survey Answers}

Two different questionnaires were provided to students and teachers to find out their perceptions of online language learning. 39 students (29 from the Faculty of Health Care and 10 from the Faculty of Business Management) and 13 English language teachers submitted their answers.

What regards the student survey (Table 1), the following tendencies emerged: students feel fully or partially satisfied with the use of Microsoft Teams (100\%) and Moodle (85\%) during their online lectures. However, students face various challenges, both technical and linguistic, while learning in the virtual environment. To the question about challenges they face in the Moodle platform students stated that writing, speaking and listening were the biggest problems (36\%), while others think that vocabulary $(28 \%)$ and other causes were a great challenge for them. Similarly, speaking (38\%), listening (38\%) and grammar (28\%) were names as the issues to deal with in the Teams platform.

The survey also focused on students' attendance of lectures during online learning. Most of the respondents (59\%) stated that their participation rate was 90$100 \%$, followed by $9 \%$ of those who claimed their attendance rate was $70-90 \%$. The question regarding the reasons of non-attendance revealed that 23 students $(59 \%)$ could not participate in lectures because of personal problems, 19 students (49\%) had issues with the quality of the internet, 13 participants (33\%) claimed that they did not attend lectures because of their work or it was too difficult to concentrate on lectures at home (12 respondents, 31\%) and 6 students (15\%) indicated that 'early hours' was a problem (i.e. when classes start at $8 \mathrm{am}$ ).

Students were also asked whether they received adequate attention from their lecturers during the online classes. The answers revealed that 16 students (41\%) were fully satisfied with the attention they got while 18 respondents $(46 \%)$ were partially satisfied, and just 5 students (13\%) claimed they felt shortage of the lecturers' attention.

Moreover, the question of the content (exercises) in the Moodle platform was raised. A big proportion of the participants (33\%) claimed that all the content which was provided in this platform was understandable, however quite a number of students $(46 \%)$ still think that they need some instructions and rules in order to complete the tasks in time. Just a small minority of the respondents (10\%) find the exercises too difficult. What regards Microsoft Teams, 33\% of the participants claimed that they understand everything clearly and only for 8 of them $(21 \%)$ felt 
that further instructions were needed.

To sum up, what regards specifically language learning, students indicated having various problems and admitted that it was not very easy: only $36 \%$ of the respondents rated this experience as 'excellent' or 'very good' and 54\% as ,good' or 'average'. Overall, the vast majority of the respondents $(92 \%)$ seem to be fully or partially satisfied with online learning at Vilniaus kolegija/University of Applied Sciences and with their academic achievements..

Table 1. Student survey

\begin{tabular}{|c|c|c|c|}
\hline $\begin{array}{l}\text { In which faculty do you study } \\
\text { foreign languages? }\end{array}$ & Health Care - 29 & $\begin{array}{c}\text { Business } \\
\text { Management }-10\end{array}$ & Others - 0 \\
\hline $\begin{array}{l}\text { Which foreign language do you learn } \\
\text { online? }\end{array}$ & English - 39 & German - 0 & French - 0 \\
\hline $\begin{array}{l}\text { Which platform was used for foreign } \\
\text { language lectures? }\end{array}$ & Teams - 38 & Moodle - 30 & Zoom - 1 \\
\hline $\begin{array}{l}\text { Is the Moodle platform suitable for foreign } \\
\text { language teaching? }\end{array}$ & Yes - 29 & Yes/No - 8 & No - 2 \\
\hline $\begin{array}{l}\text { Which challenges do you face in the Moodle } \\
\text { platform? }\end{array}$ & $\begin{array}{c}\text { Writing - } 19 \\
\text { Speaking - } 14 \\
\text { Listening - } 14\end{array}$ & Vocabulary - 11 & $\begin{array}{l}\text { Other } \\
\text { problems } \\
-4\end{array}$ \\
\hline $\begin{array}{l}\text { Is the Teams platform suitable for foreign } \\
\text { language learning? }\end{array}$ & Yes - 31 & Yes/No - 8 & No - 0 \\
\hline $\begin{array}{l}\text { Which challenges do you face in the Teams } \\
\text { platform? }\end{array}$ & $\begin{array}{l}\text { Speaking - } 20 \\
\text { Listening - } 15 \\
\text { Grammar - } 11\end{array}$ & Vocabulary - 9 & Other -6 \\
\hline $\begin{array}{l}\text { Do you attend lectures in the Moodle } \\
\text { platform? }\end{array}$ & $\begin{array}{c}90 / 100 \text { per cent }-23 \\
70 / 90 \text { per cent }-9\end{array}$ & $50 / 60$ per cent -4 & $>50-3$ \\
\hline $\begin{array}{l}\text { What challenges do you face regarding } \\
\text { lecture attendance? }\end{array}$ & $\begin{array}{c}\text { Personal } \\
\text { problems - } 23 \\
\text { Internet } \\
\text { challenges - } 19 \\
\text { Work - } 13 \\
\end{array}$ & $\begin{array}{c}\text { Difficulty in } \\
\text { concentration - } 12\end{array}$ & $\begin{array}{c}\text { Early } \\
\text { hours - } 6\end{array}$ \\
\hline $\begin{array}{l}\text { Did you receive a sufficient amount of } \\
\text { lecturers' attention during online learning? }\end{array}$ & Yes/No - 18 & Yes - 16 & No - 5 \\
\hline $\begin{array}{l}\text { Were exercises understandable on the } \\
\text { Moodle platform? }\end{array}$ & $\begin{array}{c}\text { Yes, with } \\
\text { instructions - } 18\end{array}$ & Yes - 13 & $\begin{array}{l}\text { Not really } \\
-4\end{array}$ \\
\hline $\begin{array}{l}\text { Which exercises were hard to do in online } \\
\text { classes? }\end{array}$ & $\begin{array}{l}\text { Listening - } 17 \\
\text { Speaking - } 16\end{array}$ & Grammar - 14 & Other - 1 \\
\hline $\begin{array}{l}\text { How would you rate your experience of } \\
\text { learning a foreign language during the } \\
\text { pandemic? }\end{array}$ & $\begin{array}{c}\text { Good - } 15 \\
\text { Very good - } 12\end{array}$ & Excellent - 2 & Average - 6 \\
\hline $\begin{array}{l}\text { Is the Moodle platform suitable for foreign } \\
\text { language learning? }\end{array}$ & Yes/No - 21 & Yes - 13 & No - 5 \\
\hline $\begin{array}{l}\text { Are you satisfied with online learning/ } \\
\text { achieved level of English? }\end{array}$ & Yes - 18 & Yes/No - 18 & No - 3 \\
\hline
\end{tabular}


The second questionnaire about the effectiveness of online teaching of foreign languages was provided to teachers (Table 2). 13 teachers out of 15 (87\% response rate) that belong to the Centre of Foreign Languages at Vilniaus kolegija/University of Applied Sciences submitted their answers. They teach students in 7 different faculties; some of them teach several different courses in different faculties.

In line with the European Union regulations on foreign languages, students with foreign language proficiency level B1 and B2 comprise the biggest proportion of the audience. Students at $\mathrm{C} 1$ level make up just $4-5 \%$ of the audience.

Not surprisingly then, the majority of the teachers (69\%) indicated that their students lack writing skills, followed by $38 \%$ of those who think that students' listening skills are poor.

What concerns trends in students' language skills, $54 \%$ of the respondents indicated that students' speaking skills increased, while $15 \%$ think that they decreased. Quite a number of the respondents (31\%) believe that the main decrease was observed in students' writing skills.

The researchers were interested in the factors that facilitate or obstruct online learning process therefore a question about students' general competencies was asked. The answers revealed that the majority of teachers $(77 \%)$ believe that students first of all lack independent learning skills, followed by personal/social and writing skills (38\%). The researchers assume that these are serious issues that may hinder online learning.

What regards the tools for online teaching, 2 main platforms were engaged: Moodle and Microsoft Teams. The Moodle platform received slightly less positive feedback: only 3 of the respondents (23\%) believe that the Moodle platform is fully suitable for virtual lessons, while the majority of respondents $(62 \%)$ view it as only partially suitable. There are several reasons for such answers, the main being that the Moodle platform is not convenient for speaking activities. Meanwhile the Teams platform received full approval from 9 teachers $(69 \%)$ and partial approval from 3 teachers (23\%). Overall, a vast majority of the respondents find both tools either fully or partially satisfying.

The respondents also noticed that students participate more actively in online lectures compared to face-to-face lessons. 9 teachers $(69 \%)$ claim that the attendance of students makes up $70-90 \%, 3$ of them (23\%) think that attendance of students is up to $90-100 \%$ in general.

Moreover, about half of the surveyed teachers believe their students received a sufficient amount of their attention and felt no lack of consultations. A slightly smaller proportion of the surveyed students $(41 \%)$ confirmed that the attention they received from their teachers was sufficient.

What regards the content provided in the above-mentioned platforms, the respondents admit that their students encountered some problems with different types of activities, including speaking (31\%), writing (46\%), grammar $(23 \%)$ and listening $(23 \%)$. This is consistent with the students answers who indicated that 
they encountered speaking, writing and listening problems

Overall, the survey generated a full range of answers and the respondents seem to have to deal with numerous challenges, but they look for solutions by engaging various tools, like virtual rooms, video calls, document sharing and presentations. It is necessary to observe the development of the situation. Regular feedback from students and teachers is essential to facilitate the teaching/learning process and ensure high quality education.

Table 2. Teacher Survey

\begin{tabular}{|c|c|c|c|}
\hline $\begin{array}{l}\text { Which discipline(s) } \\
\text { do you teach? }\end{array}$ & $\begin{array}{c}\text { Specialty } \\
\text { language - } 7 \\
\text { Professional } \\
\text { English - } 6\end{array}$ & $\begin{array}{c}\text { Business } \\
\text { English - } 5 \\
\text { Business } \\
\text { German - 2 }\end{array}$ & $\begin{array}{l}\text { English - } 5 \\
\text { Others - } 5\end{array}$ \\
\hline Do you work with A0 and A1 level students? & No -8 & Yes - 3 & Other - 2 \\
\hline Do you work with A2 level students? & No -5 & Yes - 6 & Other - 2 \\
\hline Do you work with B1 level students? & Yes- 6 & No -3 & Other -3 \\
\hline Do you work with B2 level students? & Yes - 9 & No - 2 & Other - 2 \\
\hline Do you work with $\mathrm{C} 1$ level students? & Yes- 7 & No -4 & Other -2 \\
\hline $\begin{array}{l}\text { Which linguistic competences do you think your } \\
\text { students lack? }\end{array}$ & $\begin{array}{l}\text { Writing - } 9 \\
\text { Listening - } 5\end{array}$ & Reading - 2 & Other - 3 \\
\hline $\begin{array}{l}\text { Do you think the level of foreign language has } \\
\text { decreased? }\end{array}$ & $\begin{array}{l}\text { No - } 5 \\
\text { Yes, writing - } 4\end{array}$ & $\begin{array}{c}\text { Yes, } \\
\text { speaking - } 2 \\
\text { Yes, } \\
\text { listening - 1 }\end{array}$ & Other - 4 \\
\hline $\begin{array}{l}\text { Do you think the level of foreign languages has } \\
\text { increased? }\end{array}$ & $\begin{array}{c}\text { Yes, speaking - } 7 \\
\text { No }-4\end{array}$ & $\begin{array}{l}\text { Yes, } \\
\text { reading - } 4\end{array}$ & $\begin{array}{l}\text { Yes, } \\
\text { listening } \\
-4\end{array}$ \\
\hline $\begin{array}{l}\text { What general competences do you think your } \\
\text { students lack? }\end{array}$ & $\begin{array}{c}\text { Learning - } 10 \\
\text { Writing -5 } \\
\text { Cultural } \\
\text { awareness - } 4\end{array}$ & $\begin{array}{c}\text { Bilingualism } \\
-3\end{array}$ & $\begin{array}{l}\text { Personal, } \\
\text { social - } 5\end{array}$ \\
\hline $\begin{array}{l}\text { What general competences do you teach during } \\
\text { lectures? }\end{array}$ & $\begin{array}{c}\text { Cultural } \\
\text { awareness - } 10 \\
\text { Personal, } \\
\text { social - } 10 \\
\end{array}$ & $\begin{array}{c}\text { Learning - } 10 \\
\text { Business - } 7\end{array}$ & $\begin{array}{c}\text { Citizenship } \\
-8 \\
\text { Writing - } 2\end{array}$ \\
\hline $\begin{array}{l}\text { Which platform was used for online teaching of the } \\
\text { foreign language? }\end{array}$ & Teams - 12 & Moodle - 9 & Other - 2 \\
\hline Is Moodle suitable for foreign language teaching? & Yes/No - 8 & Yes - 3 & Other - 6 \\
\hline $\begin{array}{l}\text { What challenges did students face in the Moodle } \\
\text { platform? }\end{array}$ & Speaking - 7 & Other - 8 & $\begin{array}{l}\text { Grammar, } \\
\text { writing - } 2\end{array}$ \\
\hline Is Teams suitable for foreign language teaching? & Yes - 9 & Yes/ No - 3 & Other - 3 \\
\hline $\begin{array}{l}\text { What challenges did students face in the Teams } \\
\text { platform? }\end{array}$ & Other -8 & $\begin{array}{c}\text { Grammar, } \\
\text { vocabulary }-4\end{array}$ & $\begin{array}{l}\text { Speaking } \\
-2\end{array}$ \\
\hline Did students actively participate in online lectures? & $70 / 90$ per cent -9 & $\begin{array}{c}90 / 100 \\
\text { per cent }-3\end{array}$ & $\begin{array}{c}50 / 60 \text { per } \\
\text { cent }-1\end{array}$ \\
\hline $\begin{array}{l}\text { Do you think your students received enough } \\
\text { attention during online lectures? }\end{array}$ & Yes- 7 & Yes/No -2 & Other -4 \\
\hline
\end{tabular}




\begin{tabular}{|l|c|c|c|}
\hline Was there a lack of consultations for your students? & No -6 & Yes- 4 & Yes/No -2 \\
\hline $\begin{array}{l}\text { What exercises/activities did your students find } \\
\text { difficult to do? }\end{array}$ & Writing - 6 & $\begin{array}{c}\text { Speaking -4 } \\
\text { Grammar - 3 }\end{array}$ & $\begin{array}{c}\text { Listening } \\
-3\end{array}$ \\
\hline $\begin{array}{l}\text { Which specific Teams tools did you use during the } \\
\text { lectures? }\end{array}$ & $\begin{array}{c}\text { Presentations } \\
-11 \\
\text { Documents } \\
\text { sharing - 11 }\end{array}$ & $\begin{array}{c}\text { Video Call - 8 } \\
\text { Virtual rooms } \\
-7\end{array}$ & $\begin{array}{c}\text { Writing } \\
-11\end{array}$ \\
\hline
\end{tabular}

\section{Conclusions}

The research revealed general global tendencies and highlighted positive and negative aspects of online teaching/learning after two semesters of virtual classes at Vilniaus kolegija/University of Applied Sciences:

1. Analysis of a number of studies published in the period March - May 2021 suggests that online learning is a new reality imposed by the Covid-19 pandemic that both teachers and students struggle to adapt to. As the shift from traditional face-to-face learning to online learning was unexpected, it certainly generated numerous challenges that need to be tackled.

2. The most common challenges seem to be lack of administrative support, lack of readiness for exclusively online teaching/learning resulting in lack of confidence, and motivation issues.

3. The majority of the surveyed students at Vilniaus kolegija/UAS were found to be satisfied with online learning and their academic achievements, which is consistent with previous research data obtained in other countries, such as Croatia, Turkey and Indonesia.

4. The main problems encountered by students at Vilniaus kolegija/ University of Applied Sciences include both technical and linguistic issues, and students expressed a need for greater help from teachers in the form of instructions or extra consultations.

5. Students' improved attendance was indicated by the teachers as an important advantage of online learning compared to traditional learning, which is consistent with the results of a study conducted in Croatia.

6. Two main tools engaged in online language learning at Vilniaus kolegija/ University of Applied Sciences - Microsoft Team and Moodle platforms - proved to be efficient in online learning and were found satisfying by the majority of both teachers and students.

7. Further research into the subject of online teaching/learning is needed to monitor the development of the situation. Regular feedback from students and teachers is essential in order to facilitate the process of online learning and boost its efficiency. 


\section{Literature}

Ali, W. (2020). Online and Remote Learning in Higher Education Institutes: A Necessity in Light of COVID-19 Pandemic. Higher Education Studies, 10(3), 16-25. Prieiga per EBSCOhost doi:10.5539/hes.v10n3p16

Ananga, P. (2020). Pedagogical considerations of e-learning in education for development in the face of COVID-19. International Journal of Technology in Education and Science (IJTES), 4(4), 310-321. Prieiga per EBSCOhost http:// web.a.ebscohost.com/ehost/detail/detail?vid=17\&sid=d74f64ed-9173-429d-86552737ab387256\%40sdc-v-sessmgr02\&bdata $=$ JnNpdGU9ZWhvc3QtbG12ZQ\%3d\% $3 \mathrm{~d} \# \mathrm{AN}=\mathrm{EJ} 1271209 \& \mathrm{db}=$ eric

Alqahtani, A. Y., \& Rajkhan, A. A. (2020). E-Learning Critical Success Factors during the COVID-19 Pandemic: A Comprehensive Analysis of E-Learning Managerial Perspectives. Education Sciences, 10. Prieiga per EBSCOhost doi:10.3390/educsci10090216

Baber, H. (2020). Determinants of Students' Perceived Learning Outcome and Satisfaction in Online Learning during the Pandemic of COVID19. Journal of Education and E-Learning Research, 7(3), 285-292. Prieiga per EBSCOhost DOI: 10.20448/journal.509.2020.73.285.292

Basilaia, G., \& Kvavadze, D. (2020). Transition to Online Education in Schools during a SARS-CoV-2 Coronavirus (COVID-19) Pandemic in Georgia. Pedagogical Research, 5(4). Prieiga per EBSCOhost https://doi.org/10.29333/pr/7937

Bryson, J. R., \& Andres, L. (2020). COVID-19 and Rapid Adoption and Improvisation of Online Teaching: Curating Resources for Extensive versus Intensive Online Learning Experiences. Journal of Geography in Higher Education, 44(4), 608-623. Prieiga per EBSCOhost DOI: 10.1080/03098265.20 20.1807478

Cohen, E., \& Davidovitch, N. (2020). The Development of Online Learning in Israeli Higher Education. Journal of Education and Learning, 9(5), 15-26. Prieiga per EBSCOhost doi:10.5539/jel.v9n5p15

Dhawan, S. (2020). Online Learning: A Panacea in the Time of COVID-19 Crisis. Journal of Educational Technology Systems, 49(1), 5-22. Prieiga per EBSCOhost DOI: 10.1177/0047239520934018

Durak, G., \& Çankaya, S. (2020). Undergraduate Students' Views about Emergency Distance Education during the COVID-19 Pandemic. Online Submission, 5(1), 122-147. Prieiga per EBSCOhost DOI:10.46827/ejoe.v5i1.3441

Elumalai, K. V., Sankar, J. P., Kalaichelvi,R., John, J. A., Menon, N., Alqahtani, M. S. N., \& Abumelha. M. A. (2020). Factors affecting the quality of e-learning during the COVID-19 pandemic from the perspective of higher education students. Journal of Information Technology Education: Research, 19, 731-753. Prieiga per EBSCOhost https://doi.org/10.28945/4628

Johnson, N., Veletsianos, G., \& Seaman, J. (2020). U.S. faculty and 
administrators' experiences and approaches in the early weeks of the COVID-19 pandemic. Online Learning, 24(2), 6-21. Prieiga per EBSCOhost https://doi. org/10.24059/olj.v24i2.2285

Korkmaz, G. \& Toraman, Ç. (2020). Are we ready for the postCOVID-19 educational practice? An investigation into what educators think as to online learning. International Journal of Technology in Education and Science (IJTES), 4(4), 293-309. Priega per EBSCOhost http://web.a.ebscohost.com/ehost/ detail/detail?vid=9\&sid=d74f64ed-9173-429d-8655-2737ab387256\%40sdc-v-sess mgr02\&bdata $=$ JnNpdGU9ZWhvc3QtbG12ZQ\%3d\%3d\#AN=EJ1271308\&db=eric

Kusumawati, A. J. (2020). Redesigning Face-to-Face into Online Learning for Speaking Competence during COVID-19: ESP for Higher Education in Indonesia. International Journal of Language Education, 4(2), 276-288. Prieiga per EBSCOhost https://doi.org/10.26858/ijole.v4i2.14745

Marshall, H. W., \& Kostka, I. (2020). Fostering Teaching Presence through the Synchronous Online Flipped Learning Approach. TESL-EJ, 24(2). Prieiga per EBSCOhosthttp://web.a.ebscohost.com/ehost/detail/detail?vid=12\&sid=d74f64ed9173-429d-8655-2737ab387256\%40sdc-v-sessmgr02\&bdata=JnNpdGU9ZWhvc3 QtbG12ZQ\%3d\%3d\#AN=EJ1268565\&db=eric

Murphy, L., Eduljee,N. B.,\& Croteau, K. (2020). College Student Transition to Synchronous Virtual Classes during the COVID-19 Pandemic in Northeastern United States. Pedagogical Research, 5(4). Prieiga per EBSCOhost https://doi. org $/ 10.29333 / \mathrm{pr} / 8485$

Puljak, L., Čivljak, M., Haramina, A., Mališa, S., Čavić, D., Klinec, D., Aranza, D., Mesarić, J., Skitarelić, N., Zoranić, S., Majstorović, D., Neuberg, M., Mikšić, Š., \& Ivanišević, K. (2020). Attitudes and concerns of undergraduate university health sciences students in Croatia regarding complete switch to e-learning during COVID-19 pandemic: a survey. BMC Medical Education, 20(1), 416. Prieiga per EBSCOhost https://doi.org/10.1186/s12909-020-02343-7

Stern, J. Introduction to Online Teaching and Learning. Prieiga per internetą: http://www.wlac.edu/online/documents/otl.pdf

Torun, E. D. (2020). Online Distance Learning in Higher Education: E-Learning Readiness as a Predictor of Academic Achievement. Open Praxis, 12(2), 191-208. Prieiga per EBSCOhost https://dx.doi.org/10.5944/ openpraxis.12.2.1092

Unger, S., \& Meiran, W. R. (2020). Student attitudes towards online education during the COVID-19 viral outbreak of 2020: Distance learning in a time of social distance. International Journal of Technology in Education and Science (IJTES), 4(4), 256-266. Prieiga per EBSCOhost http://web.a.ebscohost.com/ehost/detail/ detail?vid=15\&sid=d74f64ed-9173-429d-8655-2737ab387256\%40sdc-v-sessmgr0 2\&bdata $=$ JnNpdGU9ZWhvc3QtbG12ZQ\%3d\%3d\#AN=EJ1271377\&db=eric 


\title{
NUOTOLINIS ANGLŲ KALBOS MOKYMAS(IS) „COVID-19““ PANDEMIJOS METU: VILNIAUS KOLEGIJOS STUDENTŲ IR DĖSTYTOJŲ VERTINIMAS
}

\author{
Viktorija Prapraitė, Virginija Andriusevičienè \\ Vilniaus kolegija
}

\section{Santrauka}

Straipsnyje analizuojami nuotolinio mokymo sunkumai ir privalumai. COVID-19 pandemija privertè visas švietimo institucijas skubiai pereiti prie nuotolinio mokymo, nepaisant, ar jos buvo tam pasiruošusios, ar ne. Literatūros apžvalga rodo, kad visos institucijos patyrè tam tikrų sunkumų ir turejjo spręsti įvairias problemas. Pagrindinès šios dienos švietimo aktualijos tapo diskusijos dèl studentų ir dèstytojų (ne)pasirengimo dirbti nuotoliniu būdu ir dèl to kylančių baimių bei objektyvių ir subjektyvių sunkumų, o taip pat dèl mokymo(si) įrankių ir metodų, nes visa tai lemia švietimo kokybę. Vilniaus kolegija taip pat organizavo nuotolines paskaitas, pagrindiniais nuotolinio mokymo ịrankiais pasirinkusi Moodle ir Microsoft Teams. Praejus metams nuo nuotolinio mokymo pradžios buvo atliktas tyrimas siekiant išsiaiškinti studentų ir dėstytojų nuomonę apie minėtų įrankių tinkamumą nuotoliniam užsienio kalbų (anglų kalbos) mokymui(si). Tyrimo problema buvo studentų galimas pasitenkinimas/nepasitenkinimas skubiu perėjimu prie nuotolinio mokymo(si) ir to padariniai akademiniams pasiekimams. Buvo iškelta hipotezė, kad studentai gali jaustis nepatenkinti drastiškais pokyčiais mokymosi procese, kai naudojami nauji ịrankiai, metodai ir darbo formos, ir kad tie pokyčiai gali lemti studentų prastesnius akademinius pasiekimus. Atliktos studentų $(\mathrm{N}=39)$ ir dèstytojų $(\mathrm{N}=13)$ apklausos parodė, kad absoliuti dauguma respondentų yra visiškai arba iš dalies patenkinti nuotoliniu darbu. Net $92 \%$ studentų nurodè, kad jie yra visiškai (46 \%) arba iš dalies (46\%) patenkinti tiek nuotoliniu mokymu(si), tiek akademiniais rezultatais. Microsoft Teams įrankis sulaukè kiek daugiau populiarumo nei Moodle virtualaus mokymosi platforma. Dėstytojų apklausa atskleide, kad $92 \%$ apklaustųjų yra patenkinti Microsoft Teams įrankiu ir $85 \%$ - Moodle platforma. Respondentai taip pat nurode ir nuotolinio mokymo(si) procese patiriamus sunkumus, kurie apima tiek techninius, tiek ir kalbinius aspektus. Autoriai daro išvadą, kad apskritai nuotolinis mokymas(is) yra vertinamas teigiamai, tačiau yra gerintinų aspektų: studentams reikia pagalbos mokantis naudotis nuotolinio mokymosi ịrankiais, reikia aiškiau formuluoti užduotis Moodle aplinkoje ir būti pasirengusiems daugiau konsultuoti studentus. Tolesni tyrimai leistų stebèti, kaip keičiasi situacija ir kaip ją galima tobulinti.

Reikšminiai žodžiai: aukštasis mokslas, kalbų mokymas, nuotolinis mokymas, COVID-19 pandemija 


\section{AUTORIŲ LYDRAŠTIS}

Autoriaus vardas, pavardė: Viktorija Prapraitè

Mokslo laipsnis ir vardas: magistro laipsnis, lektorè

Darbo vieta ir pareigos: Vilniaus kolegijos Užsienio kalbų centras, lektore Autoriaus mokslinių interesų sritys: užsienio kalbos dẻstymo metodika, ESP, nuotolinis mokymas, lyderyste

Telefonas ir el. pašto adresas: 864727 957, v.prapraite@ekf.viko.lt

Autoriaus vardas, pavardè: Virginija Andriusevičienè

Mokslo laipsnis ir vardas: magistro laipsnis, lektoré

Darbo vieta ir pareigos: Vilniaus kolegijos Užsienio kalbų centras, lektore

Autoriaus mokslinių interesų sritys: užsienio kalbos dėstymo metodika, ESP, nuotolinis mokymas, tarpkultūrinè komunikacija

Telefonas ir el. pašto adresas: 869992 334; v.andriuseviciene@spf.viko.lt

\section{AUTHORS' COVER LETTER}

Author's name and surname: Viktorija Prapraite

Academic degree and name: Master's degree, lecturer

Workplace and position: Lecturers at the Centre of Foreign Languages, Vilniaus kolegija/UAS

Author's research interests: foreign language teaching methodology, ESP, online teaching

Telephone and e-mail address: +37064727957, v.prapraite@ekf.viko.lt

Author's name and surname: Virginija Andriusevičienè

Academic degree and name: Master's degree, lecturer

Workplace and position: Lecturer at the Centre of Foreign Languages, Vilniaus kolegija/UAS

Author's research interests: foreign language teaching methodology, ESP, online teaching, intercultural communication

Telephone and e-mail address: +370 699 92334;

v.andriuseviciene@spf.viko.lt 